\title{
The habitat of Coccidioides spp. and the role of animals as reservoirs and disseminators in nature
}

\author{
María del Rocío Reyes-Montes', María Ameyali Pérez-Huitrón, Jorge Luis Ocaña-Monroy', \\ María Guadalupe Frías-De-León ${ }^{2}$, Erick Martínez-Herrera ${ }^{1}$, Roberto Arenas ${ }^{3}$ and Esperanza Duarte-Escalante ${ }^{1 *}$
}

\begin{abstract}
Background: Coccidioidomycosis, a potentially fatal fungal infection, is considered an emergent mycotic disease because of the increased incidence of fungal infections registered over recent years. Infection occurs through the inhalation of arthroconidia from two main species of Coccidioides: Coccidioides immitis and C. posadasii, which are both endemic to arid and semi-arid regions of North America. Coccidioides species not only infect humans but can also infect other mammals (land, aquatic, wild or domestic), reptiles and birds.

Objective: To obtain information regarding the habitat of Coccidioides spp. and the animals infected by this fungus and to identify the role that infected animals play as reservoirs and disseminators of this fungus in nature.

Materials: A literature review was conducted to identify the habitat of Coccidioides spp. and the infected non-human animal species targeted by this fungus.

Results and conclusions: This review allows us to suggest that Coccidioides spp. may be classified as halotolerant organisms; nevertheless, to perpetuate their life cycle, these organisms depend on different animal species (reservoirs) that serve as a link with the environment, by acting as disseminators of the fungi in nature.
\end{abstract}

Keywords: Coccidioides spp., Reservoir, Habitat, Dissemination

\section{Background}

Coccidioidomycosis, a potentially fatal fungal infection, is considered an emergent mycotic disease because of the increased incidence of infections registered in recent years [1]. Infection occurs through the inhalation of arthroconidia from two species of Coccidioides: Coccidioides immitis and C. posadasii [2], which are both endemic to arid and semi-arid regions of North America. The zones most affected by this mycosis are endemic regions of the southwestern United States of America (USA), northern Mexico, Central America and some regions of South America [3, 4]. Coccidioides spp. inhabit the soil throughout these endemic regions; therefore, understanding the habitat occupied by this fungus is important to identify the epidemiology of the

\footnotetext{
* Correspondence: dupe@unam.mx

${ }^{1}$ Departamento de Microbiología y Parasitología, Facultad de Medicina,

Universidad Nacional Autónoma de México (UNAM), Ciudad Universitaria No. 3000, Coyoacán, 04510 México Cd.Mx., Mexico

Full list of author information is available at the end of the article
}

mycotic human disease. However, coccidioidomycosis not only occurs in humans but may also affect several animal species, a fact that has not received much attention but nonetheless relevant for establishing the role of animals as vectors in the epidemiology of this disease in humans [5].

The objective of this study was to review the information in the literature regarding the habitat of Coccidioides spp. and the animal species affected by coccidioidomycosis. This information may aid in elucidating the role of infected animal species as reservoirs and disseminators of disease.

\section{Discussion}

Habitat of Coccidioides spp.

Regions that are endemic for coccidioidomycosis are generally characterized by a semi-arid climate that facilitates the spread of Coccidioides spores in the air. The mild winter weather typical of endemic regions provides optimal conditions for the growth of the fungus, and the dry, hot summers facilitate the dispersion of the 
arthroconidia [3, 6, 7]. However, the distribution of Coccidioides spp. in the soil of endemic regions is irregular, even in regions with a high incidence of infection [8].

The first studies to describe the habitat of Coccidioides were those of Egebert et al. [9], and Elconin et al. [10] and Lacy and Swatek [11]; those researchers obtained fungal isolates from soil samples with a high salinity and suggested that elevated soil salinity may be a requirement for fungal development. The spores of Coccidioides are also known to grow in sandy alkaline soils that are rich in organic matter and salts [7, 12-14]. Fisher et al. [15] confirmed that the habitat of Coccidioides in endemic regions is characterized also by soils with high levels of essential nutrients such as iron, calcium and magnesium. Moreover, additional findings from Fisher et al. [15] support the ability of this fungus to grow in nearly any type of desert soil, including those with low $\mathrm{pH}$ levels; this fungus can also tolerate extreme air temperatures ranging from -40.0 to $48.8^{\circ} \mathrm{C}$ and soil temperatures ranging from -6.5 to $60.5{ }^{\circ} \mathrm{C}$. The authors also emphasize that abiotic factors in endemic zones may provide favourable conditions for the growth of Coccidioides. Greater organic content in the soil may lead to a greater availability of nutrients for fungal growth, whereas increased salinity and high temperatures may decrease the competition with other microorganisms. For example, high concentrations of sodium borate in the soil may be antiseptic to some microorganisms but not necessarily to Coccidioides [15]. More recently, work by De Macedo et al. [16] confirmed the environmental characteristics described previously for the habitat of Coccidioides spp. through the positive identification of Coccidioides isolates in soil samples obtained from semiarid regions in the state of Piauí, in the northeastern region of Brazil.

Dabrowa et al. [17] determined the presence of potentially pathogenic fungi in intertidal zones. Although the authors were unable to confirm positive isolates of $C$. immitis, it is possible that this fungus may be present in intertidal zones considering the endemic presence of Coccidioides throughout the southwestern USA. Moreover, it was previously demonstrated that C. immitis is able to survive in seawater and saturated salt water for up to 6 weeks in the laboratory [18]. Importantly, even under these conditions, $C$. immitis maintains the ability to infect various aquatic species such as river crabs, goldfish, bottle nose dolphins and lion fish [18]. The concentration of $C$. immitis in these sediments is naturally elevated during the rainy season as the result of ocean or river runoff [3]. In Mexico, despite successful clinical isolations of Coccidioides spp., the screening of environmental samples has had low effectiveness, so that Catalán-Dibene et al. [19] explored a highly endemic area near the USA and Mexico border, where previously detected Coccidioides by molecular methods [20]. In this study they tested the serum of 40 trapped rodents using ELISA, and detected antibodies against Coccidioides in two species: Peromyscus maniculatus and Neotoma lepida. This study sets the basis for analyzing this pathogen in its natural environment.

Baptista-Rosas et al. [21] generated a model for the distribution of Coccidioides species by using a combination of several environmental variables and geospatial reference points in the USA and Mexico, which are places with positive Coccidioides isolates. This model suggests that arid soils in North American deserts are likely to serve as ecological niches for Coccidioides, in agreement with the greater incidence of disease in these regions and findings by others [9-11].

Currently, findings by various studies agree regarding the ecological traits that define the habitat of Coccidioides. This type of fungus is associated with soils in arid, semi-arid and alkaline regions that have sparse xerophytic vegetation, elevated average temperatures and a low annual average rainfall [15]. Therefore, the ability of Coccidioides to survive under such extreme conditions represents an advantage over other microorganisms, as suggested by Baumgardner [5]. Based on work by De Hoog [22], the Coccidioides genus consists of xerotolerant fungi because they can grow under extreme hostile conditions. Moreover, Coccidioides may be considered halotolerant organisms [23], because both species in this genus tolerate high salt concentrations of up to $8 \%[2,24,25]$. Nevertheless, little is known about the mechanisms that species of Coccidioides utilize to survive under high salinity conditions. Some strategies that Coccidioides may utilize to survive under these conditions may include: (1) maintaining high intracellular salt concentrations, osmotically or at least equivalent to its external concentration ("salt-in" strategy) allowing for it to adapt to an alkaline environment. However, this requires a special adaptation of its intracellular systems; and (2) maintaining low salt concentrations in its cytoplasm ("compatible-solute" strategy). The osmotic pressure of the medium is balanced by compatible solutes (2-sulfotrehalose, trehalose, saccharose, glycerol, betaine glycine, ectoin and glycosilglycerol). These solutes do not affect the enzymatic activity as high concentrations of inorganic salts do not require a special adaptation of intracellular systems [23]. However, it remains to be determined which strategies are used by Coccidioides to survive under conditions of high salinity.

\section{Role of animals as reservoirs}

It has been suggested that animals may play a role in soil enrichment by serving as a substrate or growth factor for some pathogens [5]. For example, the growth of Histoplasma capsulatum or Cryptococcus neoformans is 
favoured in soils rich in animal-derived excrements and organic matter [5].

Authors have proposed for more than five decades that animal carcasses may serve as a medium for the growth of Coccidioides in the soil [26-28]. This was supported by the finding of fungus-positive isolates near animal burrows [29-31], in contrast, isolates from soil without animal contact were negative for the fungus [32]. It is important to emphasize that although some work suggests the existence of "hot spots" in endemic zones or areas where the presence of Coccidioides is highly probable [21], attempts to isolate the fungus from the soil have been unsuccessful. Nonetheless, coccidioidomycosis has typically been considered a "classical" soil-acquired infection [5]. However, work by [24] emphasized the role of animals in the life cycle of Coccidioides, with the finding of fungus-positive isolates in samples collected from animal burrows in the city of Solonolpoles in the state of Ceara, in northeastern Brazil. This city is located at an elevation of 155.38 metres above sea level, has an average temperature of $26-28.8^{\circ} \mathrm{C}$, has a rainy season from January to April with an average annual precipitation of $700 \mathrm{~mm}$ and contains xerophytic vegetation. Solonolpoles is located in a semi-arid region of Brazil and is characterized by high temperatures, frequent drought and friable soil. These characteristics are in agreement with those previously described for the habitat of Coccidioides spp. and provide further support to the idea that animals may enrich the soil and act as an important growth factor for this fungus [5]. Additionally, it has been proposed that infected animals, such as bats and armadillos, may form part of the life cycle of Coccidioides and thus act as reservoirs of the fungus [30, 33, 34].

Recent findings from comparative genomic analyses suggest that Coccidioides spp. contain a significant number of genes that are important for host interactions, and the number of genes involved in host interactions is greater than those important for survival in their natural habitat [35]. This trend is further supported by the finding of numerous changes in the genetic makeup of Coccidioides, with the biggest change occurring in the number of genes that are important for survival in natural habitats. For example, the decrease of genes involved in cell wall degradation (cellulase, tannase, cutinase and pectin lyase) occurs together with an expansion in the number of genes involved in the use of carcasses as an energy source (protease and keratinase). Some of these genes encode protease families, such as extracellular serine proteases, aspartic proteases, and Meps. At least ten Mep genes (designated as Mep1 to Mep10) have been found in Coccidioides posadasii, and most of them were classified into the M35 (deuterolysin) and M36 (fungalysin) families [36]. In sum, these changes suggest that Coccidioides spp. are not typical soil fungi in that they maintain a close association with keratin-rich animals both during the infection of a living host and after the host has died by growing in the carcass as mycelium $[35,37]$.

Overall, these findings may suggest that the location of Coccidiodes spp. in the environment is intricately tied to the activities of their host. The low number of fungus isolates from soil samples appears to agree with the observation that Coccidiodes are better adapted to a life cycle that includes an animal host. In addition to the lower number of fungus isolates that can be obtained from soil samples, the finding that most of the positive soil isolates are found in association with organic matter derived from animal carcasses further supports intricate host interactions. Therefore, based on these findings, we propose that the life cycle of Coccidioides spp. in the natural soil habitat may be brief. Once Coccidioides spp. infect a host, disease may progress, leading ultimately to the death of the host and providing new organic matter seeded with fungal particles. The high temperatures in these endemic zones, combined with the elevated levels of carbon dioxide that result from the process of decomposition, provide an optimal environment for the dimorphic transformation of the parasitic structures (spherules) of Coccidioides, giving rise to the infective forms (arthroconidia). Upon completion of this life cycle, new infective fungi are available for dispersion by established mechanisms [38] (Fig. 1), thus allowing the fungi to rapidly infect new hosts and re-start the cycle. Therefore, the time spent by the fungus without host interaction is brief, which partly explains the difficulty of obtaining fungus-positive isolates from soil samples (Fig. 1). The brief existence of Coccidioides spp. in the absence of a host may be related to the extreme environmental conditions of the ecological niche. The high salt concentrations in the soil or water present an energetically costly challenge to life. Under conditions of high salinity, the fungus must maintain ionic concentration gradients to ensure osmotic equilibrium [39]. The extreme environmental conditions have driven adaptive changes in the genome of Coccidioides spp., leading to the acquisition of a small number of new genes that are mostly associated with the interactions between the fungus and their animal hosts [35]. Therefore, these genetic changes ensure the use of animals as reservoirs by Coccidioides spp., which appear to provide a favourable environment for fungal development.

The extreme environmental conditions present in the natural soil habitat of Coccidioides spp. are not favourable for the sexual reproduction of the fungus because this process requires greater energy expenditure [23]. We suggest that Coccidioides spp. tend to reproduce asexually in the natural habitat; in contrast, when the fungus encounters a suitable animal host, sexual 


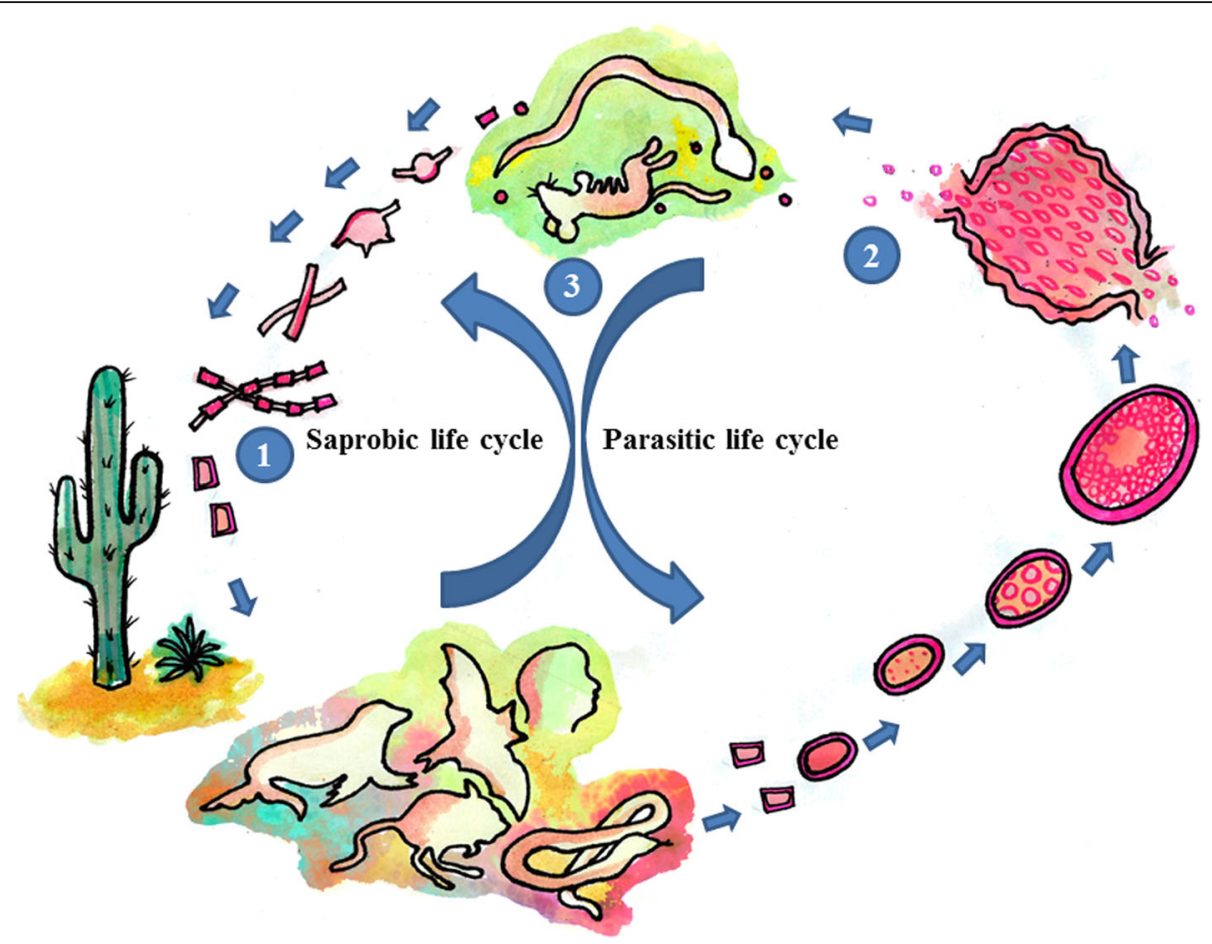

Fig. 1 Fungi belonging to the genus Coccidioides inhabit arid and semi-arid zones with alkaline soils and extreme temperatures. Under these conditions, they grow in a mycelial form and develop asexual reproductive structures. (1) These structures may be dispersed by the wind and find a host, primarily mammals, including humans, where dimorphic changes occur, giving rise to a parasitic form that has spherules and endospores. (2), Hundreds of endospores are released, and each endospore has the capacity to give rise to another spherule, repeating the life cycle in the host. In humans, the infection may progress to disease, or it may be eradicated by the immune system. Similarly, in animals, the infection may or may not lead to disease. In the case of disease and eventual death of the host, Coccidioides become exposed to the environment and return to a mycelial form (3), thus becoming integrated once again into their habitat

reproduction may resume, although sexual reproduction has not been demonstrated in Coccidioides spp., there are evidences for this type of reproduction [40-42]. These changes in reproduction modalities according to habitat may partly explain the genetic variability in Coccidioides spp. [43].

\section{Mechanisms for the dissemination of Coccidioides spp.}

Coccidioidomycosis has been reported in a number of animal species (Table 1); however, to date, the role of animals in the epidemiology of the human disease has not been fully considered.

It has been suggested that domestic land animal species and wild animal species may act as disseminators of Coccidioides in the environment, for example, as a result of poor practices for carcass disposal. Pathogenic fungi, including Coccidioides spp., can grow "in vitro" in the inorganic components of bones. Therefore, carcasses of infected animals may harbour pathogenic Coccidioides spp. and serve as an ecological niche or reservoir from which the pathogenic fungus may be easily dispersed by the wind and rapidly transported over long distances [44, 45] (Fig. 1). The wind moving over infected carcasses or bones may generate bioaerosols [46], this is a likely mechanism of dispersion. Another important characteristic of Coccidioides spp. that ensures survival under extreme environmental conditions is their ability to deposit melanin within their cell wall and within the cytoplasm of arthroconidia, spherules and endospores, excluding fungal hyphae. Melanin deposition provides protection from extreme temperatures and ultraviolet radiation (UV) and, generally, from solar radiation [47, 48]. Gostinčar et al. [23] proposed a mechanism by which melanin may protect the fungus Hortae werneckii from high salinity. This fungus is able to synthesize 1, 8-dihydroxy-melanin as a protection from osmotic stress, which suggests that Coccidioides spp. that are also able to synthesize melanin may utilize similar protective mechanisms against hypersalinity. Additionally, Coccidioides produces hydrophobins that help this fungus to adapt and survive in their environment. It is interesting to speculate how these fungal structural components relate to different phenomena occurring at the surfaces that they encounter [49]. At the microorganism level, surface phenomena or conditions become the dominant force, 
Table 1 Findings of Coccidioides spp. in non-human animals

\begin{tabular}{|c|c|c|}
\hline Specie & Diagnostic & Reference \\
\hline \multicolumn{3}{|l|}{ Terrestrial mammals in captivity } \\
\hline $\begin{array}{l}\text { Panthera tigris tigris } \\
\text { (bengal tiger) }\end{array}$ & $\begin{array}{l}\text { Post-mortem (histopathology } \\
\text { and serology) }\end{array}$ & [64] \\
\hline Macropus rufus (kangaroo) & $\begin{array}{l}\text { Post-mortem (histopathology } \\
\text { and serology) }\end{array}$ & [65] \\
\hline $\begin{array}{l}\text { Macaca mulatta } \\
\text { (rhesus monkey) }\end{array}$ & $\begin{array}{l}\text { Post-mortem (histopathology } \\
\text { and serology) }\end{array}$ & [66] \\
\hline $\begin{array}{l}\text { Theropithecus gelada } \\
\text { (primate) }\end{array}$ & $\begin{array}{l}\text { Post-mortem } \\
\text { (histopathology) }\end{array}$ & [67] \\
\hline Lama glama (llama) & $\begin{array}{l}\text { Post-mortem (histopathology } \\
\text { and serology) }\end{array}$ & [68] \\
\hline $\begin{array}{l}\text { Papio cynocephalus } \\
\text { (yellow baboon) }\end{array}$ & $\begin{array}{l}\text { Post-mortem (histopathology } \\
\text { and serology) }\end{array}$ & [69] \\
\hline $\begin{array}{l}\text { Tayassu tacaju } \\
\text { (collared peccary) }\end{array}$ & $\begin{array}{l}\text { Post-mortem } \\
\text { (histopathology) }\end{array}$ & [70] \\
\hline $\begin{array}{l}\text { Tayassu tacaju } \\
\text { (peccary) }\end{array}$ & $\begin{array}{l}\text { Post-mortem } \\
\text { (histopathology) }\end{array}$ & [71] \\
\hline Lemur catta (lemur) & Post-mortem (serology) & [72] \\
\hline Lama glama (llama) & $\begin{array}{l}\text { Post-mortem (histopathology, } \\
\text { serology and culture) }\end{array}$ & [73] \\
\hline $\begin{array}{l}\text { Mandrillus sphinx } \\
\text { (mandrill) }\end{array}$ & $\begin{array}{l}\text { Post-mortem (histopathology, } \\
\text { serology and culture) }\end{array}$ & [74] \\
\hline $\begin{array}{l}\text { Pan troglodytes } \\
\text { (chimpanzee) }\end{array}$ & $\begin{array}{l}\text { Post-mortem (histopathology, } \\
\text { serology and culture) }\end{array}$ & {$[75]$} \\
\hline $\begin{array}{l}\text { Phascolarctos cinereus } \\
\text { (koala) }\end{array}$ & $\begin{array}{l}\text { Post-mortem (histopathology } \\
\text { and serology) }\end{array}$ & [76] \\
\hline Bison antiquus (bison) & Post-mortem (histopathology) & [77] \\
\hline $\begin{array}{l}\text { Panthera tigris corbetti } \\
\text { (tiger) }\end{array}$ & $\begin{array}{l}\text { Post-mortem (histopathology } \\
\text { and serology) }\end{array}$ & [78] \\
\hline Pan troglodytes (chimpanzee) & Histopathology & [79] \\
\hline Diceros bicornis (rhino) & $\begin{array}{l}\text { Post-mortem (histology and } \\
\text { serology) }\end{array}$ & [80] \\
\hline Lama glama (llama) & $\begin{array}{l}\text { Post-mortem (histopathology, } \\
\text { serology and culture) }\end{array}$ & [81] \\
\hline $\begin{array}{l}\text { Nomascus gabriellae } \\
\text { (monkey) }\end{array}$ & Serology & [82] \\
\hline Vicugna pacos (vicuna) & $\begin{array}{l}\text { Post-mortem (histopathology, } \\
\text { serology and PCR) }\end{array}$ & [83] \\
\hline \multicolumn{3}{|l|}{ Marine mammals in captivity } \\
\hline $\begin{array}{l}\text { Zatopilus californianus } \\
\text { (sea lion) }\end{array}$ & $\begin{array}{l}\text { Post-mortem (histopathology } \\
\text { and culture) }\end{array}$ & [58] \\
\hline Enhydra lutris (otter) & Post-mortem (histopathology) & [84] \\
\hline $\begin{array}{l}\text { Zalophus californianus } \\
\text { (sea lion) }\end{array}$ & $\begin{array}{l}\text { Post-mortem } \\
\text { (histopathology and culture) }\end{array}$ & [59] \\
\hline Tursiops truncatus (dolphin) & $\begin{array}{l}\text { Post-mortem (histopathology, } \\
\text { serology and culture) }\end{array}$ & [60] \\
\hline \multicolumn{3}{|l|}{ Domestic mammals } \\
\hline Ovis aries (sheep) & Post-mortem & [85] \\
\hline Sus domestica (pig) & Post-mortem (histopathology) & [86] \\
\hline Equus caballus (mare) & Post-mortem (histopathology) & [87] \\
\hline $\begin{array}{l}\text { Ovis canadensis nelsoni } \\
\text { (ram) }\end{array}$ & $\begin{array}{l}\text { Post-mortem (histopathology } \\
\text { and culture) }\end{array}$ & [88] \\
\hline
\end{tabular}

Table 1 Findings of Coccidioides spp. in non-human animals (Continued)

\begin{tabular}{|c|c|c|}
\hline Equus caballus (mare) & Post-mortem (histopathology) & {$[89]$} \\
\hline Equus caballus (mare). & Histopathology and culture & {$[90]$} \\
\hline Equus caballus (mare) & Post-mortem (histopathology) & {$[91]$} \\
\hline Canis lupus familiaris (dog) & $\begin{array}{l}\text { Post-mortem (histopathology } \\
\text { and culture }\end{array}$ & {$[92]$} \\
\hline Equus caballus (mare) & $\begin{array}{l}\text { Post-mortem (histology and } \\
\text { serology) }\end{array}$ & {$[93]$} \\
\hline Canis lupus familiaris (dog) & Histology and X-ray & {$[94]$} \\
\hline Canis lupus familiaris (dog) & Serology and X-ray & {$[95]$} \\
\hline Equus ferus przewalskii (horse) & Records and histopathology & {$[96]$} \\
\hline Canis lupus familiaris (dog) & Serology & {$[97]$} \\
\hline Equus caballus (horse) & Serology and culture & {$[98]$} \\
\hline Felis silvestris domesticus (cat) & Serology and culture & [99] \\
\hline Canis lupus familiaris (dog) & $\begin{array}{l}\text { Post-mortem (histology and } \\
\text { serology) }\end{array}$ & \\
\hline Felis silvestris domesticus (cat) & Histopathology and serology & {$[61]$} \\
\hline \multicolumn{3}{|l|}{ Wild mammals } \\
\hline Canis latrans (coyote) & Post-mortem (histopathology) & [100] \\
\hline Felis concolor (cougar) & $\begin{array}{l}\text { Post-mortem (histopathology } \\
\text { and culture) }\end{array}$ & [101] \\
\hline Felis concolor (cougar) & Post-mortem (histopathology) & [102] \\
\hline Dasypus novemcinctus & $\begin{array}{l}\text { Post-mortem (histopathology } \\
\text { and culture) }\end{array}$ & {$[30]$} \\
\hline \multicolumn{3}{|l|}{ (armadillo) } \\
\hline $\begin{array}{l}\text { Glossophaga soricina and } \\
\text { Desmodus rotundus (bats) }\end{array}$ & $\begin{array}{l}\text { Post-mortem (histopathology } \\
\text { and serology) }\end{array}$ & [33] \\
\hline $\begin{array}{l}\text { Peromyscus maniculatus and } \\
\text { Neotoma lepida (rodents) }\end{array}$ & Post-mortem (serology) & {$[19]$} \\
\hline \multicolumn{3}{|l|}{ Reptiles } \\
\hline $\begin{array}{l}\text { Pituophis melanoleucus } \\
\text { affini (snake) }\end{array}$ & $\begin{array}{l}\text { Post-mortem (histopathology } \\
\text { and culture) }\end{array}$ & [103] \\
\hline $\begin{array}{l}\text { Masticophis flagellum } \\
\text { piceus (snake) }\end{array}$ & $\begin{array}{l}\text { Post-mortem (histopathology } \\
\text { and serology) }\end{array}$ & [104] \\
\hline \multicolumn{3}{|l|}{ Birds } \\
\hline $\begin{array}{l}\text { Gallus gallus domesticus } \\
\text { (chicken) }\end{array}$ & Post-mortem (culture) & {$[56]$} \\
\hline
\end{tabular}

$P C R$ polymerase chain reaction

whereas factors such as gravity are mostly insignificant. One of the functions of hydrophobins is to control surface forces [49]. When hyphae encounter aqueous surfaces, their surrounding hydrophobins provide a hydrophobic surface that helps in breaking the superficial tension, thus allowing the formation of micelles that separate from the aqueous media and travel through the air, increasing the efficiency by which conidia diffuse through the air [50].

The movement of humans and the migration of other mammals may serve as another mechanism for fungal 
dispersion in the environment [51]. An excellent example is the long distance migration of bats [52]. Work by Cordeiro et al. [33] demonstrated that these mammals are infected with Coccidioides spp., which may support the idea of bats as reservoirs and disseminators of this fungus. The transfer of animal species in captivity, for example, marine or terrestrial mammals from endemic zones that may be infected with Coccidioides [53] (Table 1), may serve as a mechanism for the dispersion of disease into non-endemic regions. These two forms of fungal dispersion may explain how transmission occurs in clinical cases within non-endemic zones, as those described in the state of Washington, where various cases of coccidioidomycosis have been reported, including one case of primary cutaneous coccidioidomycosis, two cases of pneumonia and one case that progressed to meningitis [54]. Furthermore, Litvintseva et al. [55] demonstrated persistent colonization of soils by $C$. immitis in Washington State to recent human infections [54] and confirmed genetic identity between isolates from soil and one of the case-patients.

This dispersal method would also provide an explanation for a positive C. posadasii isolate that was obtained from a patient who acquired the disease from a nonendemic region (Campeche, Mexico) and who reported no excursions away from his site of residence [25]. Another observation seldom referenced but with great relevance for the epidemiology of coccidioidomycosis is a report from Nigeria of two chickens that were analysed post-mortem and showed positive Coccidioides spp. isolates [56]. The relevance of this report lies in two specific elements: first, it represents the first report of coccidioidomycosis in the non-endemic region of Nigeria; second, it is the first report of the infection in birds, confirming that Coccidioides spp. are able to infect non-mammals. Another interesting case is that of a 14-year-old Chinese boy who had never visited or had been exposed to any imported materials from zones endemic for Coccidioides and yet was infected and suffered from coccidioidomycosis. Nevertheless, the boy was reported to have experienced an episode of drowning in the sea [57]. Although the source of the infection was unclear, it is known that Coccidioides can survive in salt water [18], and they are known to be present in marine mammals [58-60]. It is speculated that marine currents may be able to drag the arthroconidia towards non-endemic zones. These facts suggest that the area of geographic distribution for Coccidioides is expanding and that the fungi responsible for coccidioidomycosis are adapting to new habitats that may have characteristics different from those previously described [25].

Animal-to-animal transmission requires direct contact, such as handling infected animals at the clinic or direct inoculation with infected material [61], which occurs in an animal bite [62]. This concept is supported by the work of Lacy and Swatek [11] who reported on the finding of viable spherules in the tissue and secretion of animals.

There are various reports of coccidioidomycosis in domestic animals that have been confirmed by serologic evidence [63]. This poses a problem for public health because the presence of Coccidioides spp. in these animals suggests that they may serve as disseminators of the fungus and therefore be a possible danger to human health.

\section{Conclusions}

The fungi that belong to the genus Coccidioides may be considered halotolerant organisms because they can survive and develop in environments with high salinity. These organisms can tolerate other environmental extreme conditions, such as high temperatures. To survive, these organisms rely on specific mechanisms that protect them against the damaging effects of extreme environmental conditions. Ultimately, life under extreme conditions may elicit changes in the reproduction, evolution, genetic makeup and speciation of these fungi. Therefore, it is important to gain knowledge about how Coccidioides spp. respond to stress and to understand how climate changes or human activity influence microbial diversity and evolution. To ensure their life cycle, Coccidioides spp. require animal reservoirs that probably serve as links with the environment by acting as disseminators of the fungi in nature.

\section{Abbreviations \\ ELISA: Enzyme-Linked ImmunoSorbent Assay; Meps: Metallo-proteases; \\ PCR: Polymerase chain reaction; spp.: Species; USA: United States of America; UV: Ultraviolet radiation}

\section{Acknowledgements \\ This project was supported by PAPIIT-DGAPA (IN251574). We gratefully thank Rodrigo Rosas in the elaboration of Figure.}

Funding

No funding was received for this research.

\section{Authors' contributions}

MRRM, MAPH, JLOM, MGFDL, EMH, RA, and EDE performed literature research and wrote the paper. All authors read and approved the final manuscript.

\section{Competing interests}

The authors declare that they have no competing interests.

Ethics approval and consent to participate

Not applicable.

\section{Author details}

${ }^{1}$ Departamento de Microbiología y Parasitología, Facultad de Medicina, Universidad Nacional Autónoma de México (UNAM), Ciudad Universitaria No. 3000, Coyoacán, 04510 México Cd.Mx., Mexico. ²División de Investigación, Hospital Juárez de México, Edificio E. Av. Instituto Politécnico Nacional 5160, Col. Magdalena de las Salinas, 07760 México Cd.Mx., Mexico. ${ }^{3}$ Unidad de Micología, Hospital General "Manuel Gea González", Av. Calzada de Tlalpan 4800, Tlalpan, 14080 México, Cd.Mx., Mexico. 


\section{Received: 6 November 2015 Accepted: 6 October 2016} Published online: 10 October 2016

\section{References}

1. Hector RF, Rutherford GW, Tsang CA, Erhart LM, McCotter O, Anderson SM, et al. The public health impact of coccidioidomycosis in Arizona and California. Int J Environ Res Public Health. 2011:8(4):1150-73.

2. Fisher MC, Koenig GL, Taylor JW. Molecular and phenotypic description of Coccidioides posadasii sp. nov., previously recognized as the non-California population of Coccidioides immitis. Mycologia. 2002;94(1):73-84.

3. Pappagianis D. Epidemiology of coccidioidomycosis. Curr Top Med Mycol. 1988;2:199-238

4. Hector RF, Laniado-Laborín R. Coccidioidomycosis a fungal disease of the Americas. PLoS Med. 2005;2(1):e2

5. Baumgardner DJ. Soil-related bacterial and fungal infections. J Am Board Fam Med. 2012;25(5):734-44.

6. Smith CE, Beard RR, Rosenberger HG, Whiting EG. Effect of season and dust control on coccidioidomycosis. JAMA. 1946;132(14):833-8.

7. Drutz DJ, Catanzaro A. Coccidioidomycosis. Parts I. Am Rev Respir Dis. 1978;117(3):559-85.

8. Kolivras KN, Johnson PS, Comrie AC, Yool SR. Environmental variability and coccidioidomycosis (valley fever). Aerobiologia. 2001;17:31-42.

9. Egeberg $\mathrm{RO}$, Elconin $\mathrm{AE}$, Egeberg MC. Effect of salinity and temperature on Coccidioides immitis and three antagonistic soil saprophytes. J Bacteriol. 1964;88(2):473-6

10. Elconin AF, Egeberg RO, Egeberg MC. Significance of soil salinity on the ecology of Coccidioides immitis. J Bacteriol. 1964;87(3):500-3.

11. Lacy GH, Swatek FE. Soil ecology of Coccidioides immitis at amerindian middens in California. Appl Microbiol. 1974;27(2):379-88.

12. Elconin $A F$, Egeberg $M C$, Bald JG, Matkin $A O$, Egeberg $R O$. A fungicide effective against Coccidioides immitis in the soil. In: Ajello $L$, editor. Coccidioidomycosis. Tucson: University of Arizona Press; 1967. p. 319-21.

13. Swatek FE. Ecology of Coccidioides immitis. Mycopathol Mycol Appl. 1970;41:3-12.

14. Einstein HE, Johnson RH. Coccidioidomycosis: New aspects of epidemiology and therapy. Clin Infect Dis. 1993;16(3):349-54.

15. Fisher FS, Bultman MW, Johnson SM, Pappagianis D, Zaborsky E. Coccidioides niches and habitat parameters in the southwestern United States: a matter of scale. Ann NY Acad Sci. 2007:1111:47-72

16. De Macêdo RC, Rosado AS, da Mota FF, Cavalcante MA, Eulálio KD, Filho $A D$, et al. Molecular identification of Coccidioides spp. in soil samples from Brazil. BMC Microbiol. 2011;11:108

17. Dabrowa N, Landau JW, Newcomer VD. A survey of tide-washed coastal areas southern California for fungi potentially pathogenic to man. Mycopathol Mycol Appl. 1964;24(2):137-50.

18. Dzawachiszwili N, Landau JW, Newcomer VD, Plunkett OA. The effect of sea water and sodium chloride on the growth of fungi pathogenic to man. J Invest Dermatol. 1964;43:103-9.

19. Catalán-Dibene J, Johnson SM, Eaton R, Romero-Olivares AL, Baptista-Rosas RC, Pappagianis D, Riquelme M. Detection of coccidioidal antibodies in serum of a small rodent community in Baja California, Mexico. Fungal Biol. 2014;118:330-9.

20. Baptista-Rosas RC, Catalán-Dibene J, Romero-Olivares AL, Hinojosa A, Cavazos T, Riquelme M. Molecular detection of Coccidioides spp. from environmental samples in Baja California: linking Valley Fever to soil and climate conditions. Fungal Ecol. 2015:5(2):177-90.

21. Baptista-Rosas RC, Hinojosa A, Riquelme M. Ecological niche modeling of Coccidioides spp. in western North American deserts. Ann NY Acad Sci. 2007;1111(1):35-46.

22. De Hoog S, Zalar P, Van Den Ende BG, Gunde-Cimerman N. Relation of halotolerance to human-pathogenicity in the fungal tree of life: an overview of ecology and evolution under stress. In: Gunde-Cimerman, editor. Adaptation to life at high salt concentrations in archaea bacteria, and eukarya. Springer, Printed in the Netherlands; 2005. p. 371-395.

23. Gostinčar $C$, Lenassi M, Gunde-Cimerman N, Plemenitaš A. Fungal adaptation to extremely high salt concentrations. Adv Appl Microbiol. 2011;77:71-96

24. Cordeiro RA, Brilhante RSN, Rocha MFG, Fechine MAB, Camara LMC, Camargo ZP, et al. Phenotypic characterization and ecological features of Coccidioides spp. from northeast Brazil. Med Mycol. 2006;44(7):631-9.
25. Duarte-Escalante E, Zúñiga G, Frías-De-León MG, Canteros C, CastañónOlivares LR, Reyes-Montes MR. AFLP analysis reveals high genetic diversity but low population structure in Coccidioides posadasii isolates from Mexico and Argentina. BMC Infect Dis. 2013;13:411.

26. Emmons CW. Isolation of Coccidioides from soil and rodents (1896-1970). Public Health Rep. 1942;57(4):109-11.

27. Emmons CW, Ashburn LL. The isolation of Haplosporangium parvum n. sp. and Coccidioides immitis from wild rodents. Their relationship to coccidioidomycosis. Public Health Rep (1896-1970). 1942;57(46):1715-27.

28. Nguyen C, Barker BM, Hoover S, Nix DE, Ampel NM, Frelinger JA, et al. Recent advances in our understanding of the environmental, epidemiological, immunological, and clinical dimensions of coccidioidomycosis. Clin Microbiol Rev. 2013;26(3):505-25.

29. Barker BM, Tabor JA, Shubitz LF, Perrill R, Orbach MJ. Detection and phylogenetic analysis of Coccidioides posadasii in Arizona soil samples. Fungal Ecol. 2012;5(2):163-76.

30. Eulálio KD, de Macedo RL, Salmito Cavalcanti MA, Martins LM, Lazéra MS, Wanke B. Coccidioides immitis isolated from armadillos (Dasypus novemcinctus) in the state of Piauí, northeast Brazil. Mycopathologia. 2001;149(2):57-61.

31. Maddy KT, Coccozza J. The probable geographic distribution of Coccidioides immitis in Mexico. Bol Oficina Sanit Panam. 1964;57:44-54.

32. Greene DR, Koenig G, Fisher MC, Taylor JW. Soil isolation and molecular identification of Coccidioides immitis. Mycologia. 2000;92(3):406-10.

33. Cordeiro RA, Silva KRC, Brilhante RSN, Moura FBP, Duarte NFH, Marques FJF, et al. Coccidioides posadasii infection in bats, Brazil. Emerg Infect Dis. 2012;18(4):668-70.

34. Brown J, Benedict K, Park BJ, Thompson III GR. Coccidioidomycosis: epidemiology. Clin Epidemiol. 2013;5:185-97.

35. Sharpton TJ, Stajich JE, Rounsley SD, Gardner MJ, Wortman JR, Jordar VS, et al. Comparative genomic analyses of the human fungal pathogens Coccidioides and their relatives. Genome Res. 2009:19(10):1722-31.

36. Li J, Zhang KQ. Independent expansion of zincin metalloproteinases in onygenales fungi may be associated with their pathogenicity. PLoS One. 2014;9(2):e90225. doi:10.1371/journal.pone.0090225

37. Lewis ERG, Bowers JR, Barker BM. Dust devil: the life and times of the fungus that causes Valley Fever. PLoS Pathog. 2015;11(5):e1004762. doi:10. 1371/journal.ppat.1004762.

38. Whiston E, Taylor JW. Genomics in Coccidioides: insights into evolution, ecology, and pathogenesis. Med Mycol. 2014;52(2):149-55.

39. Oren A. Bioenergetic aspects of halophilism. Microbiol Mol Biol Rev. 1999:63(2):334-48

40. Koufopanou V, Burt A, Taylor JW. Concordance of gene genealogies reveals reproductive isolation in the pathogenic fungus Coccidioides immitis. Proc Natl Acad Sci U S A. 1997;94(10):5478-82.

41. Fraser JA, Stajich JE, Tarcha EJ, Cole GT, Inglis DO, Sil A, et al. Evolution of the mating type locus: insights gained from the dimorphic primary funga pathogens Histoplasma capsulatum, Coccidioides immitis, and Coccidioides posadasii. Eukaryot Cell. 2007:6(4):622-9.

42. Mandel MA, Barker BM, Kroken S, Rounsley SD, Orbach MJ. Genomic and population analyses of the mating type loci in Coccidioides species reveal evidence for sexual reproduction and gene acquisition. Eukaryot Cell. 2007:6(7):1189-99.

43. Jewell K, Cheshier R, Cage GD. Genetic diversity among clinical Coccidioides spp. isolates in Arizona. Med Mycol. 2008:46(5):449-55.

44. Pappagianis D, Einstein H. Tempest from Tehachapi takes toll or Coccidioides conveyed aloft and afar. West J Med. 1978;129(6):527-30.

45. Laniado-Laborín R. Coccidioidomicosis: Más que una enfermedad regional. Rev Inst Nal Enf Resp Mex. 2006;19(4):301-8.

46. Sharmin S, Kishi F, Sano A, Kamei K, Nishimura K, Miyaji M. Direct invasion of bones by highly pathogenic fungi in an in vitro model and its ecological significance. Nihon Ishinkin Gakkai Zasshi. 2003:44(1):17-23.

47. Nosanchuk JD, Yu JJ, Hung CY, Casadevall A, Cole GT. Coccidioides posadasii produces melanin in vitro and during infection. Fungal Genet Biol. 2007:44(6):517-20

48. Taborda CP, da Silva MB, Nosanchuk JD, Travassos LR. Melanin as a virulence factor of Paracoccidioides brasiliensis and other dimorphic pathogenic fungi: a minireview. Mycopathologia. 2008;165(4-5):331-9.

49. De la Rosa MC, Mosso MA, Ullán C. El aire: hábitat y medio de transmisión de microorganismos. Observatorio Medioambiental. 2002;5(5):375-402 
50. Beever RE, Dempsey GP. Function of rodlets on the surface of fungal spores. Nature (London). 1978;272(5654):608-10.

51. Fisher MC, Koenig GL, White TJ, San-Blas G, Negroni R, Gutiérrez-Álvarez I, et al. Biogeographic range expansion into South America by Coccidioides immitis mirrors New World patterns of human migration. Proc Natl Acad Sci U S A. 2001;98(8):4558-62.

52. Krutzsch PH, Watson RH. Isolation of Coccidioides immitis from bat guano and preliminary findings on laboratory infectivity of bats with Coccidioides immitis. Life Sci. 1978;22(8):679-84.

53. Huckabone SE, Gulland FMD, Johnson SM, Colegrove KM, Dodd EM, Pappagianis D, et al. Coccidioidomycosis and other systemic mycoses of marine mammals stranding along the central California, USA coast: 1998-2012. J Wildl Dis. 2015:51(2):295-308.

54. Marsden-Haug N, Goldoft M, Ralston C, Limaye AP, Chua J, Hill H, et al. Coccidioidomycosis acquired in Washington State. Clin Infect Dis. 2013;56(6):847-50.

55. Litvintseva AP, Marsden-Haug N, Hurst S, Hill H, Gade L, Driebe EM, et al. Valley Fever: finding new places for an old disease: Coccidioides immitis found in Washington State soil associated with recent human infection. Clin Infect Dis. 2015;60(1):e1-3.

56. Jambalang AR, Ogo AR, Ibu IN, Gisilanbe JO, Bertu M, Jwander W, Benjamin L, Chukwukeke B, Nasir S, Sanda Y, Benshak N, Agada A, Kubo M. Coccidioidomycosis in chicken pullets in Jos, Plateau State, Nigeria: A case report. NVJ. 2010;31(3):249-51.

57. Lan F, Tong YZ, Huang H, Xiong WN, Xu YJ, Xiong SD. Primary pulmonary coccidioidomycosis in China. Respirology. 2010;15(4):722-5.

58. Reed RE, Migaki G, Cummings JA. Coccidioidomycosis in a California sea lion (Zalophus californianus). J Wildl Dis. 1976;12(3):372-5.

59. Fauquier DA, Gulland FMD, Trupkiewicz JG, Spraker TR, Lowenstine LJ. Coccidioidomycosis in free-living California sea lions (Zalophus calofornianus) in Central California. J Wildl Dis. 1996;32(4):707-10.

60. Reidarson TH, Griner LA, Pappagianis D, McBain J. Coccidioidomycosis in a bottlenose dolphin. J Wildl Dis. 1998;34(3):629-31.

61. Amorim I, Colimao MJ, Cortez PP, Dias-Pereira P. Coccidioidomycosis in a cat imported from the USA to Portugal. Vet Rec. 2011;169(9):232a.

62. Gaidici A, Saubolle MA. Transmission of coccidioidomycosis to a human via a cat bite. J Clin Microbiol. 2009;47(2):505-6.

63. Canteros CE, Madariaga MJ, Lee W, Rivas MC, Davel G, lachini R. Agentes de micosis endémicas en un área rural de Argentina: estudio seroepidemiológico en perros. Rev Iberoam Micol. 2010;27(1):14-9.

64. Henrickson RV, Biberstein EL. Coccidioidomycosis accompanying hepatic disease in two bengal tigers. J Am Vet Med Assoc. 1972;161(6):674-7.

65. Hutchinson LR, Duran F, Lane CD, Robertstad GW, Portillo M. Coccidioidomycosis in a giant red kangaroo (Macropus rufus). J Zoo Anim Med. 1973;4(1):22-4.

66. Breznock AW, Henrickson RV, Silverman S, Schwartz LW. Coccidioidomycosis in a rhesus monkey. J Am Vet Med Assoc. 1975;167(7):657-61.

67. Rapley WA, Long JR. Coccidioidomycosis in a baboon recently imported from California. Can Vet J. 1974;15(2):39-41.

68. Muir S, Pappagianis D. Coccidioidomycosis in the llama: case report and epidemiologic survey. J Am Vet Med Assoc. 1982;181(11):1334-7.

69. Rosenberg DP, Gleiser CA, Carey KD. Spinal coccidioidomycosis in a baboon. J Am Vet Med Assoc. 1984;185(11):1379-81.

70. Dillehay DL, Boosinger TR, Mackenzie S. Coccidioidomycosis in a tapir. J Am Vet Med Assoc. 1985;187(11):1233-4.

71. Lochmiller RL, Hellgren EC, Hannon PG, Grant WE, Robinson RM. Coccidioidomycosis (Coccidioides immitis) in the collared peccary (Tayassu tajacu: Tayassuidae) in Texas. J Wildl Dis. 1985;21(3):305-9.

72. Burton M, Morton RJ, Ramsay E, Stair EL. Coccidioidomycosis in a ring-tailed lemur. J Am Vet Med Assoc. 1986;189(9):1209-11.

73. Fowler ME, Pappagianis D, Ingram I. Coccidioidomycosis in llamas in the United States: 19 cases (1988-1989). J Am Vet Assoc. 1992;201:1609-14.

74. Johnson JH, Wolf AM, Edwards JF, Walker MA, Homco L, Jensen JM, et al. Disseminated coccidioidomycosis in a mandrill baboon (Mandrillus sphinx): a case report. J Zoo Wildl Med. 1998;29(2):208-13.

75. Herrin KV, Miranda A, Loebenberg D. Posaconazole therapy for systemic coccidioidomycosis in a chimpanzee (Pan troglodytes): a case report. Mycoses. 2005;48(2):447-52.

76. Burgdorf-Moisuk A, Stalis $\mathrm{IH}$, Pye GW. Disseminated coccidioidomycosis in a koala (Phascolarctos cinereus). J Zoo Wild Med. 2012;43(1):197-9.
77. Morrow W. Holocene coccidiodomycosis: Valley Fever in early holocene bison (Bison antiquus). Mycologia. 2006;98(5):669-77.

78. Helmick KE, Koplos P, Raymond J. Disseminated coccidioidomycosis in a Captive indochinese tiger (Panthera tigris corbetti) with chronic renal disease. J Zoo Wildl Med. 2006;37(4):542-4.

79. Hoffman K, Videan EN, Fritz J, Murphy J. Diagnosis and treatment of ocular Coccidioidomycosis in a female captive chimpanzee (Pan troglodytes): A case study. Ann NY Acad Sci. 2007;1111:404-10.

80. Wallace RS, Clyde VL, Steinberg H. Coccidioidomycosis in a black rhinoceros (Diceros bicornis). J Wildl Dis. 2009;40(2):365-8.

81. Coster ME, Ramos-Vara JA, Vemulapalli R, Stiles J, Krohne SG. Coccidioides posadasii keratouveitis in a llama (Lama glama). Vet Ophthalmol. 2010;13(1):53-7.

82. Goe A, Swenson J, West G, Evans J. Meningoencephalitis with secondary obstructive hydrocephalus caused by probable Coccidioides species in a buff-cheeked gibbon (Nomascus gabriellae). J Zoo Wildl Med. 2013;44(3):781-5.

83. Diab S, Johnson MS, Garcia J, Carlson EL, Pappagianis D, Smith J, et al. Case Rep: Abortion and disseminated infection by Coccidioides posadasii in an alpaca (Vicugna pacos) fetus in southern California. Med Mycol Case Rep. 2013;2:159-62.

84. Cornell LH, Osborn KG, Antrim JE. Coccidioidomycosis in a California sea otter (Enhydra lutris). J Wildl Dis. 1979:15(3):373-8.

85. Maddy KT. Coccidioidomycosis in a sheep. J Am Vet Med Assoc. 1954;124(927):465.

86. Prchal CJ, Crecelius HG. Coccidioidomycosis in a swine. J Am Vet Med Assoc. 1966;148(10):1168-9.

87. Langham RF, Beneke ES, Whitenack DL. Abortion in a mare due to coccidioidomycosis. J Am Vet Med Assoc. 1977;170(2):178-80.

88. Jessup DA, Kock N, Berbach M. Coccidioidomycosis in a desert bighorn sheep (Ovis canadensis nelsoni) from California. J Zoo Wildl Med. 1989;20(4):471-3.

89. Kramme PM, Ziemer EL. Disseminated coccidioidomycosis in a horse with osteomyelitis. J Am Vet Med Assoc. 1990;196(1):106-9.

90. Walker RL, Johnson BJ, Jones KL, Pappagianis D, Carlson GP. Coccidioides immitis mastitis in a mare. J Vet Diagn Invest. 1993;5(3):446-8.

91. Stoltz JH, Johnson BJ, Walker RL, Pappagianis D. Coccidioides immitis abortion in an arabian mare. Vet Pathol. 1994;31(2):258-9.

92. Shubitz LF, Matz ME, Noon TH, Reggiardo CC, Bradley GA. Constrictive pericarditis secondary to Coccidioides immitis infection in a dog. J Am Vet Med Assoc. 2001;218(4):537-40.

93. Maleski K, Magdesian KG, LaFranco-Scheuch L, Pappagianis D, Carlson GP. Pulmonary coccidioidomycosis in a neonatal foal. Vet Rec. 2002;151(17):505-8.

94. Jeroski A. Multicentric lymphoma and disseminated coccidioidomycosis in a dog. Can Vet J. 2003;44(1):62-4.

95. Rubensohn M, Stack S. Coccidiomycosis in a dog. Can Vet J. 2003;44(2):159-60

96. Terio KA, Stalis $H_{H}$, Allen $J$, Stott $J$, Worley MB. Coccidioidomycosis in przewalski's horses (Equus przewalskii). J Zoo Wildl Med. 2003;34(4):339-45.

97. Shubitz LF, Dial SM. Coccidioidomycosis: A diagnostic challenge. Clin Tech Small Anim Pract. 2005:20(4):220-6.

98. Higgins JC, Leith GS, Pappagianis D, Pusterla N. Treatment of Coccidioides immitis pneumonia in two horses with fluconazole. Vet Rec. 2006;159(11): 349-51.

99. Tofflemire K, Betbeze C. Three cases of feline ocular coccidioidomycosis: presentation, clinical features, diagnosis, and treatment. Vet Ophthalmol. 2010;13(3):166-72

100. Straub M, Trautman RJ, Greene JW. Coccidioidomycosis in 3 coyotes. Am J Vet Res. 1961;22:811-3.

101. Clyde VL, Kollias GV, Roelke ME, Wells MR. Disseminated coccidioidomycosis in a western cougar (Felis concolor). J Zoo Wildl Med. 1990;21(2):200-5.

102. Adaska JM. Peritoneal Coccidioidomycosis in a mountain lion in California. J Wildl Dis. 1999;35(1):75-7.

103. Timm Kl, Sonn RJ, Hultgren BD. Coccidioidomycosis in a Sonoran gopher snake, Pituophis melanoleucus affinis. J Med Vet Mycol. 1988;26(2):101-4.

104. Churgin SM, Garner MM, Swenson J, Bradway DS, French S, Kiupel M, West G. Intestinal coccidioidomycosis in a red coachwhip snake (masticophis flagellum piceus). J Zoo Wildl Med. 2013;44(4):1094-7. 